\title{
Pyrolysis of Firwood (Abies bornmülleriana Mattf.) Sawdust: Characterization of Bio-Oil and Bio-Char
}

\section{Piroliza jelove (Abies bornmülleriana Mattf.) piljevine: karakterizacija bioulja i biougljena}

\author{
Original scientific paper • Izvorni znanstveni rad \\ Received-prispjelo: 7. 11. 2013. \\ Accepted-prihvaćeno: 20. 5. 2015. \\ UDK: $630 * .813 ; 630 * 812.51 ; 674.032475 .242$ \\ doi:10.5552/drind.2015.1359
}

\begin{abstract}
This paper describes the research of slow pyrolysis of firwood (Abies bornmülleriana Mattf.) sawdust by using fixed-bed reactor. The effect of temperature ranging between 350 and $600{ }^{\circ} \mathrm{C}$ on gas, liquid and solid products was examined. The maximum bio-oil yield of $45.9 \%$ was obtained at the final pyrolysis temperature of $500{ }^{\circ} \mathrm{C}$. The elemental analysis and heating value of bio-oil and bio-char were determined, and then the chemical composition of the bio-oil was investigated using chromatographic and spectroscopic techniques such as Gas Chromatography-Mass Spectrometry (GC/MS) and Proton Nuclear Magnetic Resonance ( ${ }^{1} H$-NMR). The liquid product was mainly composed of phenolics, including 2-methoxy-phenol, 2-methyl-phenol, phenol, as well as aldeyhdes, acids, esters, alcohols and ketones. The chemical characterization has shown that the bio-oil obtained from residues of forestry production, such as firwood sawdust, can be used as an environmental feedstock, which is an ideal candidate for alternative fuels. Moreover the bio-char can be used as an energy source and active carbon.
\end{abstract}

Keywords: Bio-oil, Fir wood, GC/MS, ${ }^{1} H-N M R$, Pyrolysis

SAŽETAK • U radu je opisano istraživanje spore pirolize jelove (Abies bornmülleriana Mattf.) piljevine uz primjenu fiksnog reaktora. Analiziran je učinak temperature u rasponu od 350 do $600{ }^{\circ} \mathrm{C}$ na plinovite, tekuće i krute proizvode pirolize. Maksimalni prinos bioulja od 45,9\% dobiven je na konačnoj temperaturi pirolize od $500{ }^{\circ} \mathrm{C}$. Napravljena je elementarna analiza i određena ogrjevna vrijednost bioulja i biougljena, a zatim je ispitan kemijski sastav bioulja uz pomoć kromatografskih i spektroskopskih tehnika kao što su plinska kromatografija i masena spektrometrija (GC/MS) te protonska nuklearna magnetska rezonancija ('H-NMR). Tekući proizvodi pirolize sastavljeni su uglavnom od fenola, uključujući 2-metoksi-fenol, 2-metil-fenol, fenol, kao i od aldehida, kiselina, estera, alkohola i ketona. Kemijska su svojstva pokazala da je bioulje dobiveno od ostataka proizvodnje u šumarstvu, poput jelove piljevine, raspoloživa sirovina iz okoliša koja je idealna za alternativna goriva. Osim toga, biougljen se može koristiti kao izvor energije i kao aktivni ugljen.

Ključne riječi: bioulje, jelovina, $G C / M S,{ }^{1} H-N M R$, piroliza

\footnotetext{
Author is assistant professor at Faculty of Forestry, Department of Forest Product Engineering, Karabuk University, Karabuk, Turkey.

Autor je docent Sveučilišta u Karabuku, Šumarski fakultet, Odjel za inženjerstvo šumskih proizvoda, Karabuk, Turska.
} 


\section{INTRODUCTION}

\section{UVOD}

Renewable energy is of growing importance in satisfying environmental concerns over fossil fuel usage. Wood and other forms of biomass, including energy crops and agricultural and forestry wastes, are some of the main renewable energy resources available. This growing interest also resulted in intensive research of thermal conversion techniques for biomass, consisting of combustion, gasification and pyrolysis (Bridgwater, 2003; Janseet al., 2000). Pyrolysis is an attractive technology for converting biomass into gases, liquids (bio-oil), and char at relatively low temperature ranging between 300 and $600{ }^{\circ} \mathrm{C}$ in the absence of oxygen (Murata et al., 2012; Bu et al., 2011).

Bio-oil is referred to by many names such as pyrolysis oil, bio-crude-oil, bio-fuel-oil, wood liquids, wood oil, liquid smoke, wood distillates, pyroligneous tar, and pyroligneous acid. The bio-oil is usually dark brown and free flowing with a distinctive smoky smell. Bio-oil is a mixture of about 200 types of major and minor organic compounds and can be used for the production of chemicals and substituted for fuel-oils in many stationary applications for heat or electricity generation. The gas products can be used in engines and turbines for power generation. Bio-char can also be used as a fuel (Bridgwater, 2004; Uzun and Sarığlu, 2009; Enginaret al., 2009; Özcimen and Ersoy-Mericboyu, 2010).

As a clean fuel, bio oil has a number of practical advantages including the following:

- it is renewable and locally produced from organic waste,

- it can be stored and transported similarly to petroleum-based products,

- it is a neutral greenhouse gas and can generate carbon dioxide,

- it generates lower NOx emissions than light fuel oil in gas turbines and diesel fuel in stationary diesel engines (Sadaka, 2009).

Numerous researchers have investigated various pyrolysis processes that were developed to maximize the formation of liquid products used as fuels or chemical feedstock. Şensöz (2003) pyrolyzed pine bark ( $P i$ nusbrutiaTen.) in an externally heated fixed-bed reactor at $300^{\circ} \mathrm{C}$ and $500{ }^{\circ} \mathrm{C}$ with heating rates of 7 and 40 ${ }^{\circ} \mathrm{C} / \mathrm{min}$. The product yields were significantly influenced by the process conditions. The bio-oil was obtained at $450{ }^{\circ} \mathrm{C}$, at which the liquid product yield was maximum. In addition, the solid and liquid products were analyzed to determine their elemental composition and calorific value. Chemical fractionation of biooil showed that only low quantities of hydrocarbons were present, while oxygenated and polar fractions dominated (Şensöz, 2003). Ingram et al. (2008) have investigated pyrolysis of pinewood, pine bark, oak wood and oak bark in a continuous auger reactor. They found that the yield of bio-oil from pine was 40 to 55 $\%$ at $450{ }^{\circ} \mathrm{C}$ (Ingram et al., 2008). Wangand co-workers produced bio-oil from pine wood sawdust at differ- ent temperature ranges and analyzed the fuel properties of bio-oil. They reported that the degradation of hemicellulose started at 200 to $300{ }^{\circ} \mathrm{C}$, forming many sorts of liquid products, such as saccharide, furan, carboxylic acid, ketone and aldehyde, with the occurrence of dehydration, decarboxylation and decarbonylation, while cellulose remained unimpaired in its polymerized structure. Cellulose was substantially decomposed at 300 to $50{ }^{\circ} \mathrm{C}$, leading to a great increase in the yields of liquid and gaseous products, and simultaneously the solid residue became aromatized, which was characteristic of a concentrated lignin structure. The residue was largely decomposed to numerous guaiacols and phenols at 450 to $700{ }^{\circ} \mathrm{C}$ (Wang et al., 2009).

In this work, fir wood sawdust (AbiesbornmüllerianaMattf.) was pyrolyzed at various temperatures, using a fixed bed type reactor. The aim of this study was to elucidate the effect of temperature during slow pyrolysis on yields of the bio-oil, gas and bio-char. The chemical properties of bio-oil were characterized by GC/MS, ${ }^{1} \mathrm{H}-\mathrm{NMR}$ and elemental analysis. Also, the characterization of bio-char was performed in terms of its elemental composition and Fourier transform infrared spectroscopy (FT-IR).

\section{MATERIAL AND METHODS}

2. MATERIJAL I METODE

\subsection{Materials and sample preparation}

2.1. Materijali i priprema uzoraka

Fir wood (AbiesbornmüllerianaMattf.) was used in this study as the raw lignocellulosic biomass, which is one of the widespread and abundant species in the northwestern and Marmara regions of Turkey. Fir wood is an important commercial wood; it can be used for furniture and building materials, which produces large amounts of sawdust and wood residues every year. The raw sawdust sample supplied by the Department of Furniture and Decoration at Karabük University was ground and sieved to less than $1 \mathrm{~mm}$, and it was then dried for 12 hours at 100 to $105^{\circ} \mathrm{C}$ prior to use as a pyrolysis sample.

The proximate analysis was performed according to the ASTM standard test methods for measuring moisture contents, combustible matter and ash contents, and namely ASTM D 4442-92, ASTM E897-88 and ASTM D-1102-84, respectively. The chemical composition of feedstock was determined according to Wise and John, 1952, Rowell et al. 2005 and TAPPI standards (T-257, T-222, T-204). The ultimate analysis was conducted using an elemental analyzer (LECO CHNS-932). The oxygen content of the biomass was found by the difference. The $\mathrm{H} / \mathrm{C}$ and $\mathrm{O} / \mathrm{C}$ molar ratios were calculated from elemental composition. The HHV of the fir wood sawdust was calculated based on Dulong formula (Wang et al., 2007)

\subsection{Thermal analysis}

2.2. Toplinska analiza

The thermal decomposition of raw material was examined by using a thermogravimetric analyzer (Per- 


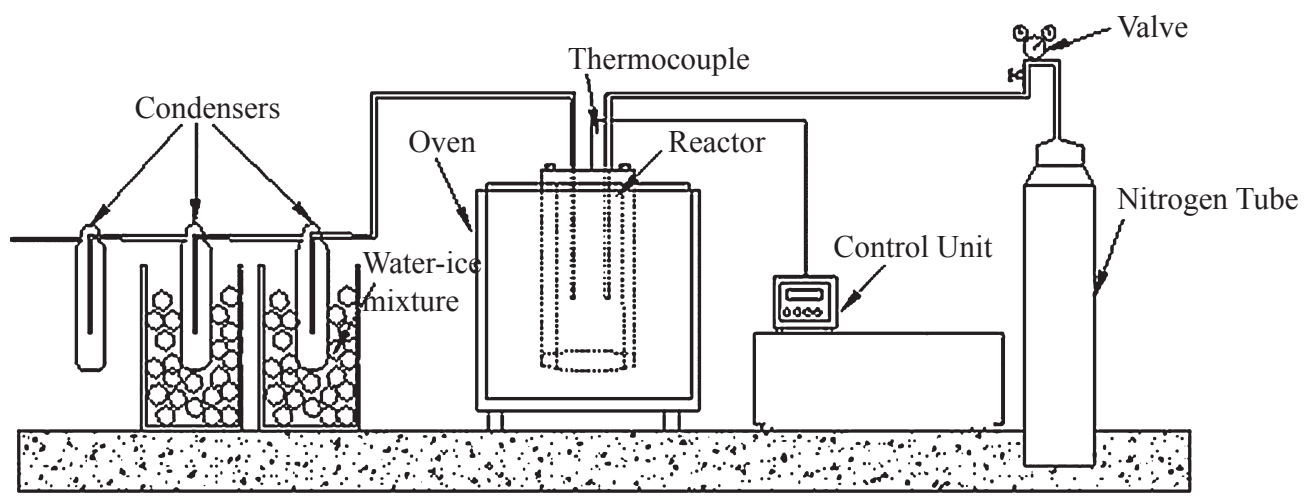

Figure 1 Schematic diagram of pyrolysis apparatus

Slika 1. Shematski prikaz uređaja za pirolizu

kin Elmer Pyris 1). For the TGA experiment, approximately $15 \mathrm{mg}$ of sample was used with a $10{ }^{\circ} \mathrm{C} / \mathrm{min}$. heating rate. Nitrogen was used as the carrier gas, with a flow rate of $25 \mathrm{ml} / \mathrm{min}$. After that, the sample was heated from $25{ }^{\circ} \mathrm{C}$ to $600{ }^{\circ} \mathrm{C}$.

\subsection{Pyrolysis
2.3. Piroliza}

Pyrolysis experiments were performed in a fixedbed reactor under a nitrogen atmosphere. The reactor has a steel cylinder with an internal diameter of $6 \mathrm{~cm}$ and a height of $21 \mathrm{~cm}$. A schematic diagram of pyrolysis apparatus is shown in Figure 1. During the experiments, heating rate and pyrolysis temperatures were controlled with a PID (Proportional-Integral-Derivative) controller. The temperature was measured every minute in the reactor using a type $\mathrm{K}$ thermocouple. In the pyrolysis experiment, a sample of $50 \mathrm{~g}$ was weighed and placed into the reactor, which was heated by an electric furnace. The temperature was increased from room temperature to $350,400,450,500,550$ and 600 ${ }^{\circ} \mathrm{C}$, while the heating rates were increased $15{ }^{\circ} \mathrm{C} / \mathrm{min}$. Experimental apparatus was held at an adjusted temperature either for a minimum of $30 \mathrm{~min}$ or until no further significant release of gas was observed. A condenser was connected to the output of the reactor and the liquid was condensed in a collector to be weighed. The bio-char collected in the reactor was weighed at the end of the experiment. The gas yield was calculated by taking the difference. Experiments were repeated at least three times within the experimental error of less than $\pm 0.5 \%$.

\subsection{Characterizations}

\subsection{Karakterizacija}

Liquid products were extracted with an equal quantity of diethyl ether. The diethyl ether extracts were analyzed by instrumental techniques such as Elemental, GC/MS and ${ }^{1} \mathrm{H}-\mathrm{NMR}$. The carbon, hydrogen and nitrogen contents of bio-oils were determined using a LECO CHNS-932 Elemental Analyzer. The oxygen content of bio-oils was found by the difference. The chemical composition of the liquid product was analyzed by GC/MS (Agilent 6890). A capillary column (HP-5, $30 \mathrm{~m} \times 0.25 \mathrm{~mm}$ i.d. $\times 0.25 \mu \mathrm{m})$ was employed to separate organic mixtures. Diethyl ether was used as solvent to dilute the dehydrated liquid product to a concentration appropriate for analysis. Helium was used as carrier gas at constant flow of $1.2 \mathrm{~mL}$. The GC oven temperature was programmed to start at $40{ }^{\circ} \mathrm{C}$, held for $10 \mathrm{~min}$, then raised at a rate of $2{ }^{\circ} \mathrm{C}$ to $170^{\circ} \mathrm{C}$, held for $5 \mathrm{~min}$, then raised to $250{ }^{\circ} \mathrm{C}$ at a rate of $8{ }^{\circ} \mathrm{C}$ held for $15 \mathrm{~min}$, then raised to $300^{\circ} \mathrm{C}$ at a rate of $15^{\circ} \mathrm{C}$, and held at this final temperature for $10 \mathrm{~min}$. The injector temperature was $250{ }^{\circ} \mathrm{C}$ with split mode. The end of the column was directly introduced into the ion source of Agilent 5973 series mass selective detector operated with electron impact ionization mode. G1035A software with a NIST library was used as data acquisition system. The ${ }^{1} \mathrm{H}-\mathrm{NMR}$ spectrum of the biooil was obtained at an $\mathrm{H}$ frequency of $300 \mathrm{MHz}$ using a BrukerUltrashield instrument. The bio-oil sample was dissolved in $\mathrm{CDCl}_{3}$.

The bio-char was characterized by elemental analysis, using a LECO CHNS-932 Elemental Analyzer. Dulong formula was used to determine the HHV of the liquid and solid products (Wang et al., 2007). Functional group chemical analysis of the bio-char was carried out using Fourier transform infrared (FT-IR) spectrometry (Nicolet iS10FT-IR spectrum instrument).

\section{RESULTS AND DISCUSSION} 3. REZULTATI I RASPRAVA

\subsection{Characteristics of fir wood sawdust}

3.1. Obilježja jelove piljevine

The main characteristics of the biomass (fir wood sawdust) are listed in Table 1. The dry wood sample contained $0.36 \%$ ash. Elemental analysis showed that it contained $46.99 \% \mathrm{C}, 6.37 \% \mathrm{H}$, and $46.64 \% \mathrm{O}_{2}$ (in mass percent, dry basis).

\subsection{TGA analysis of fir wood sawdust}

3.2. TGA analiza jelove piljevine

Thermogravimetric (TG) and derived thermogravimetric (DTG) curves of fir wood sawdust are shown in Figure 2. According to Figure 2, the moisture was removed from the raw material up to $100{ }^{\circ} \mathrm{C}$ and the main decompositions of fir wood started around $250{ }^{\circ} \mathrm{C}$ with a sharp incline to $600^{\circ} \mathrm{C}$. Wörmeyer et al., 2011 reported that the rapid weight loss between 200 and $600{ }^{\circ} \mathrm{C}$ is due to the breakup of inter-unit linkages 
Table1 Main characteristics of fir wood sawdust

Tablica 1. Glavna obilježja jelove piljevine

\begin{tabular}{|c|c|c|}
\hline Characteristics / Obilježje & Method / Metoda & Value / Vrijednost \\
\hline Moisture content, \% / sadržaj vode, \% & ASTM D-4442-92 & 6.81 \\
\hline \multicolumn{3}{|c|}{ Proximate analysis ${ }^{\mathrm{a}} \boldsymbol{\mathrm { o }}$ / neposredna analiza, $\%$} \\
\hline Volatiles / hlapljive tvari & ASTM E-897-88 & 78.32 \\
\hline Ash / pepeo & ASTM D-1102-84 & 0.36 \\
\hline Fixed carbon / fiksni ugljik & Calculated from difference / izračunano iz razlike & 14.51 \\
\hline \multicolumn{3}{|l|}{ Ultimate analysis ${ }^{\mathrm{a}}, \%$ / Konačna analiza, $\%$} \\
\hline Carbon / ugljik & & 46.99 \\
\hline Hydrogen / vodik & & 6.37 \\
\hline Oxygen / kisik & Calculated from difference / izračunano iz razlike & 46.64 \\
\hline $\mathrm{H} / \mathrm{C}$ molar ratio / H/C molarni omjer & & 1.61 \\
\hline $\mathrm{O} / \mathrm{C}$ molar ratio / O/C molarni omjer & & 0.74 \\
\hline \multicolumn{3}{|c|}{ Component analysis ${ }^{\mathrm{a}}, \%$ / Analiza sastavnica, $\%$} \\
\hline$\alpha$-cellulose / $\alpha$-celuloza & Rowell et al., 2005 & 43.53 \\
\hline Holocellulose / holoceluloza & Wise and John, 1952 & 73.70 \\
\hline Lignin / lignin & TAPPI T 222 om-02 & 30.33 \\
\hline Extractive / ekstraktivi & TAPPI T $204 \mathrm{~cm}-97$ & 2.69 \\
\hline $\mathrm{HHV}^{\mathrm{b}}, \mathrm{MJ} / \mathrm{kg}$ & Calculated from Dulong Formula & 16.65 \\
\hline
\end{tabular}

${ }^{a}$ Weight percentage on dry basis / postotak na bazi suhe tvar $/ \mathrm{b}(\mathrm{HHV})$ calculated by the Dulong Formula, that is, $\mathrm{HHV}(\mathrm{MJ} / \mathrm{kg})=0.338 \mathrm{C}+1.428(\mathrm{H}-$ $\mathrm{O} / 8)+0.095 \mathrm{~S}$

and evaporation of monomeric phenol units (Wörmeyeret al., 2011). Thermogravimetric analysis (TGA) has been widely used, because it is an easy technique to evaluate pyrolysis of wood and other lignocellulosic biomass. Similar trend was observed in previous studies (Yang et al., 2007; Ertaş and Alma, 2010; Wagenaar et al., 1993).

\subsection{Product yields}

\subsection{Udjeli proizvoda pirolize}

Pyrolysis of fir wood sawdust was carried out in the temperature range of 350 to $600{ }^{\circ} \mathrm{C}$ at intervals of $15^{\circ} \mathrm{C}$, and each yield of pyrolytic products (bio-oil, gas and bio-char) is shown in Figure 3. These experiments revealed that the quantitative composition of pyrolysis products was clearly affected by the temperature. At $350{ }^{\circ} \mathrm{C}$, the solid product (bio-char) yield reached its highest value $(38.8 \%)$. Since increasing the pyrolysis temperature decreases char yield, the char yield decreased down to $26.5 \%$ at $600{ }^{\circ} \mathrm{C}$. The bio-oil yield was $39.9 \%$ at the pyrolysis temperature of 350 ${ }^{\circ} \mathrm{C}$. The yield of bio-oil was maximized at approximately $46 \%$ at $500{ }^{\circ} \mathrm{C}$, and at the final temperature of 600 ${ }^{\circ} \mathrm{C}$, the bio-oil yield was decreased to $44.8 \%$. This was

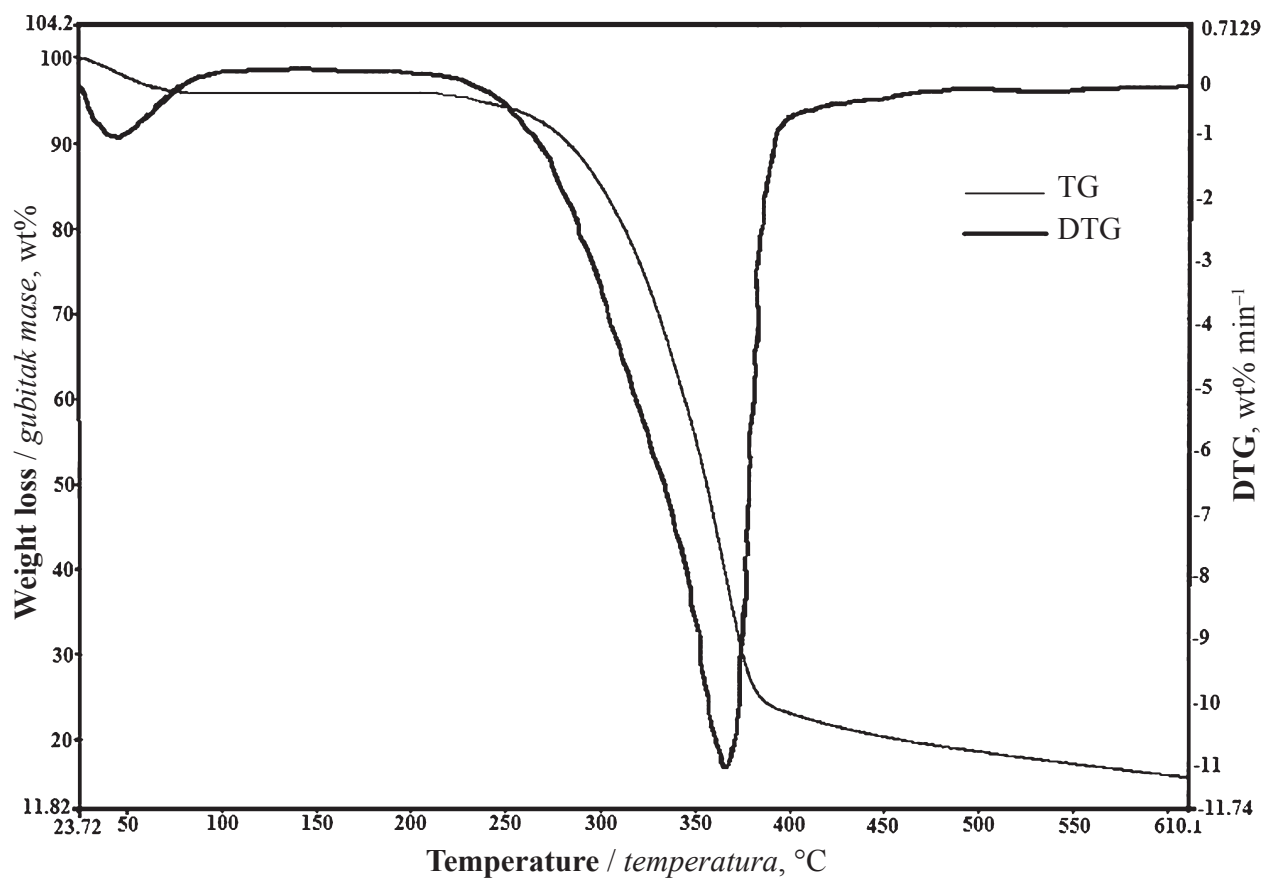

Figure 2 TG and DTG curves of fir wood under nitrogen atmosphere Slika 2. TG I DTG krivulje jelove piljevine u atmosferi dušika 


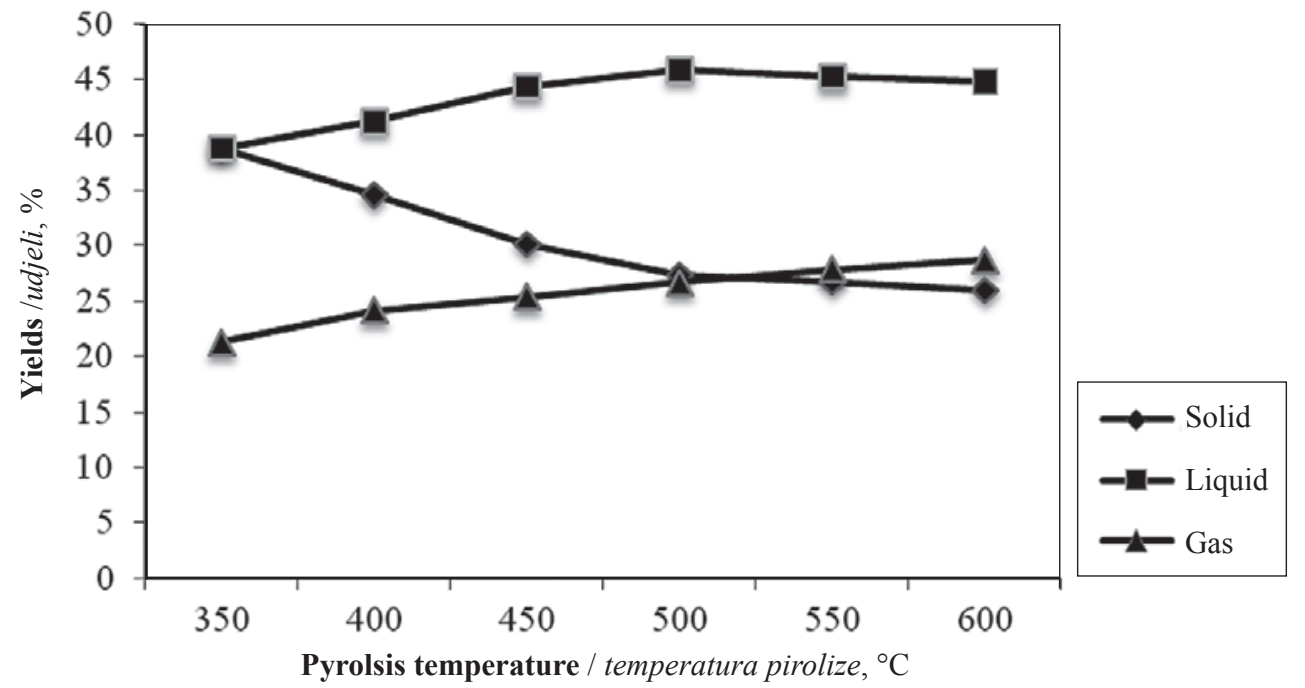

Figure 3 Yields of pyrolysis products

Slika 3. Udjeli proizvoda pirolize

due to the secondary reactions of the heavy-molecularweight compounds in the pyrolysis vapors, which is known to become active at temperatures over $500{ }^{\circ} \mathrm{C}$ (Fagbemiet al., 2001). As reported in previous studies, pyrolysis temperature plays an important role on the yields of pyrolysis products (Chen et al., 2008;Heoet al., 2010; Lee et al.,2005; Dumanet al., 2011; Özbay, 2012).

\subsection{Characterization of bio-oil}

\subsection{Karakterizacija bioulja}

The bio-oil selected for the characterization was obtained at the pyrolysis conditions that gave the maximum bio-oil yield. The elemental composition, $\mathrm{H} / \mathrm{C}$ and $\mathrm{O} / \mathrm{C}$ molar ratio and $\mathrm{HHV}$ of bio-oil are listed in Table 2.

As it shown in Table 2, the oxygen content was lower in bio-oil than in raw material. Since the decrease in oxygen content of the bio-oil (31.23\%) compared to the original feedstock $(46.64 \%)$ is significant, it can be used as the transport fuel. Furthermore, comparison of $\mathrm{H} / \mathrm{C}$ ratios with conventional fuels indicates that $\mathrm{H} / \mathrm{C}$ ratios of the bio-oil obtained in this study are less than those of light and heavy petroleum products. The higher heating value, calculated by Dulong formula, was 25.12 $\mathrm{MJ} / \mathrm{kg}$. The heating value of the bio-oil was higher than that of the raw material $(16.65 \mathrm{MJ} / \mathrm{kg})$. It can be seen that a significant decrease in the oxygen content resulted in an increase in the heating value. Results were in accordance with the previous studies reported in literature (Pütünet al.,2005; Sheng and Azevedo, 2005).
Biomass pyrolysis vapors consist of volatile compounds and non-volatile oligomers. GC/MS was only able to determine the volatile organic compounds. In the research, the ion chromatogram was obtained from the pyrolysis of the fir wood sawdust. A total of 32 major compounds were identified as given in Table 3. The GC/MS chromatogram of the bio-oil is illustrated in Figure 4. The compounds identified in bio-oil are also listed in Table 3. As shown in Table 3, the biooil was mainly composed of phenolics, including 2-methoxy-phenol, 2-methyl-phenol, 4-methyl-phenol, 4-ethyl-2-methoxy-phenol, 2-methoxy-4-vinylphenol, 2,6-dimethyl-phenol, 3-methyl-phenol,phenol and 2-methoxy-4-(2-propenyl)-phenol, 2-methoxy4-(1-propenyl)-phenol, 2-methoxy-4-propenyl-phenol as well as aldeyhdes, acids, esters, alcohols and ketones. Phenols and methoxy group are generally considered as the pyrolysis products of lignin, while hemicelluloses can be decomposed to acetic acid andaldehydes such as furfural, and cellulose can be decomposed to ketones, aldehydes and furans (Özbayet al, 2013, Pütünet al., 2005; Ren et al., 2012; Heigenmoseret al., 2013; Özçifçi and Özbay, 2013).

Phenols derived from biomass pyrolysis oils are valuable chemicals and can be used as intermediates in the synthesis of pharmaceuticals, for the production of adhesives and the synthesis of specialty polymers, while furfural is a useful organic reagent for the production of medicines, resins, food additives, fuel additives and other special chemicals (Žilnik and Jazbinšek, 2012; Shen et al., 2010; Shen and Gu, 2009). The

Table 2 Elemental composition of bio-oil ${ }^{\mathrm{b}}$

Tablica 2. Elementarni sastav bioulja

\begin{tabular}{|l|c|c|c|c|c|c|}
\hline Component & $\begin{array}{c}\mathbf{C} \\
\%\end{array}$ & $\begin{array}{c}\mathbf{H} \\
\%\end{array}$ & $\begin{array}{c}\mathbf{O}^{\mathrm{a}} \\
\%\end{array}$ & $\mathbf{H} / \mathbf{C}$ & $\mathbf{O} / \mathbf{C}$ & $\begin{array}{c}\mathbf{H H V} \\
\mathbf{M J} / \mathrm{kg}\end{array}$ \\
\hline Komponenta & 61.93 & 6.84 & 31.23 & 1.31 & 0.37 & 25.12 \\
\hline
\end{tabular}

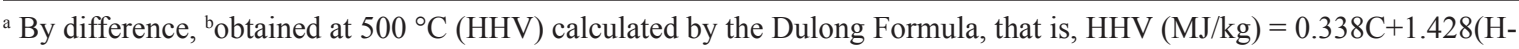
$\mathrm{O} / 8)+0.095 \mathrm{~S}$ 


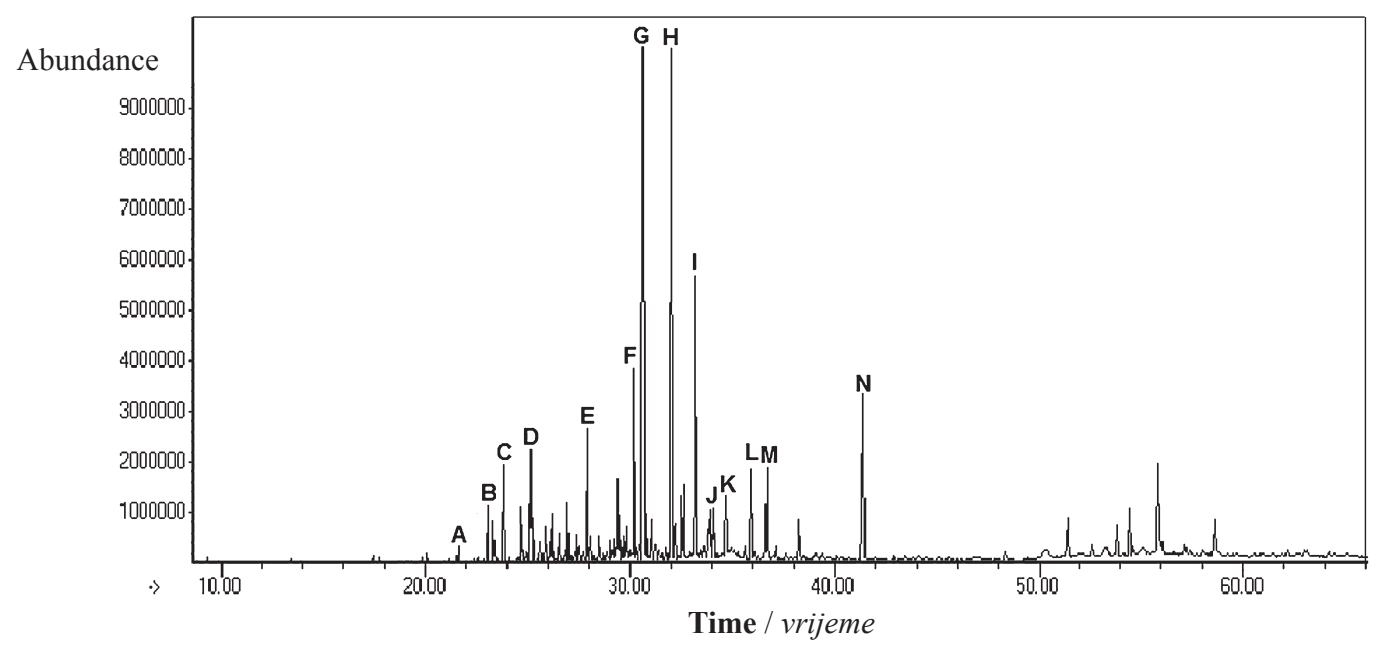

A: 2-cyclopenten-1-one, B: 2-methyl-2-cyclopenten-1-one, C:furfural D: 2-furanmethanol, E: 1,2-cyclopentenedione, F: 2-hydroxy-3-methyl-2-cyclopenten-1-on, G: 2-methoxy-phenol, H: 4-methyl-phenol, I: 4-ethyl-2-methoxy-phenol, J: 2-methoxy-4-(2-propenyl)-phenol, K: 3-methyl-phenol, L: 2-methoxy-4-(2-propenyl)-phenol, M: 2-methoxy-4-vinyl-phenol, N: 2-methoxy-4-propenyl-phenol

Figure $4 \mathrm{GC} / \mathrm{MS}$ chromatogram of bio-oil

Slika 4. GC/MS kromatogram bioulja

chemical composition of bio-oil was matched with previous GC/MS studies (Lu et al., 2011; Beiset al., 2002, Acıkgoz and Kockar, 2009; Liawet al., 2012; Luo et al., 2004; Bu et al., 2011).

The ${ }^{1} \mathrm{H}-\mathrm{NMR}$ spectrum of the bio-oil is given in Figure 5. It can be seen that the bands between 6.5 and 9 ppm were assigned to aromatic structures. Resonances between 5 and $6.5 \mathrm{ppm}$ indicate that the aromatic species were largely phenolic compounds. Aromatic ringjoining methylene protons were observed in the bio-oil and their characteristic peaks were in the resonances ranging between 3.3-4.5 ppm. The results showed that larger proportions of aliphatic structural units existed in the bio-oil from the pyrolysis of fir wood. These findings are consistent with the results of GC/MS analysis. Onay (2007) noticed that the bio-oils mainly contain aliphatic protons at carbon atoms bonded to other aliphatic carbon atoms (Onay, 2007). The products found in the bio-oil correspond well to the literature data (Demiral and Ayan, 2011; Lu et al., 2010).

\subsection{Characterization of bio-char \\ 3.5. Karakterizacija biougljena}

Elemental composition and an HHV value of the bio-char are presented in Table 4. As shown in Table 4, the bio-char, obtained from pyrolysis of fir wood sawdust, consisted of $77.28 \%$ carbon and $18.81 \%$ oxygen. It has an $\mathrm{HHV}$ of $28.35 \mathrm{MJ} / \mathrm{kg}$. An H/C molar ratio of 0.60 and an $\mathrm{O} / \mathrm{C}$ molar ratio of 0.18 were found. The elemental compositions of the bio-char were found to be better than that of the original feedstock since their carbon content was the highest. This carbon-rich product shows potential as an alternative solid fuel in the form of briquettes and pellets (Kim et al., 2011).

Figure 6 shows the FT-IR spectra of both raw material and bio-char. Changes in functional groups of

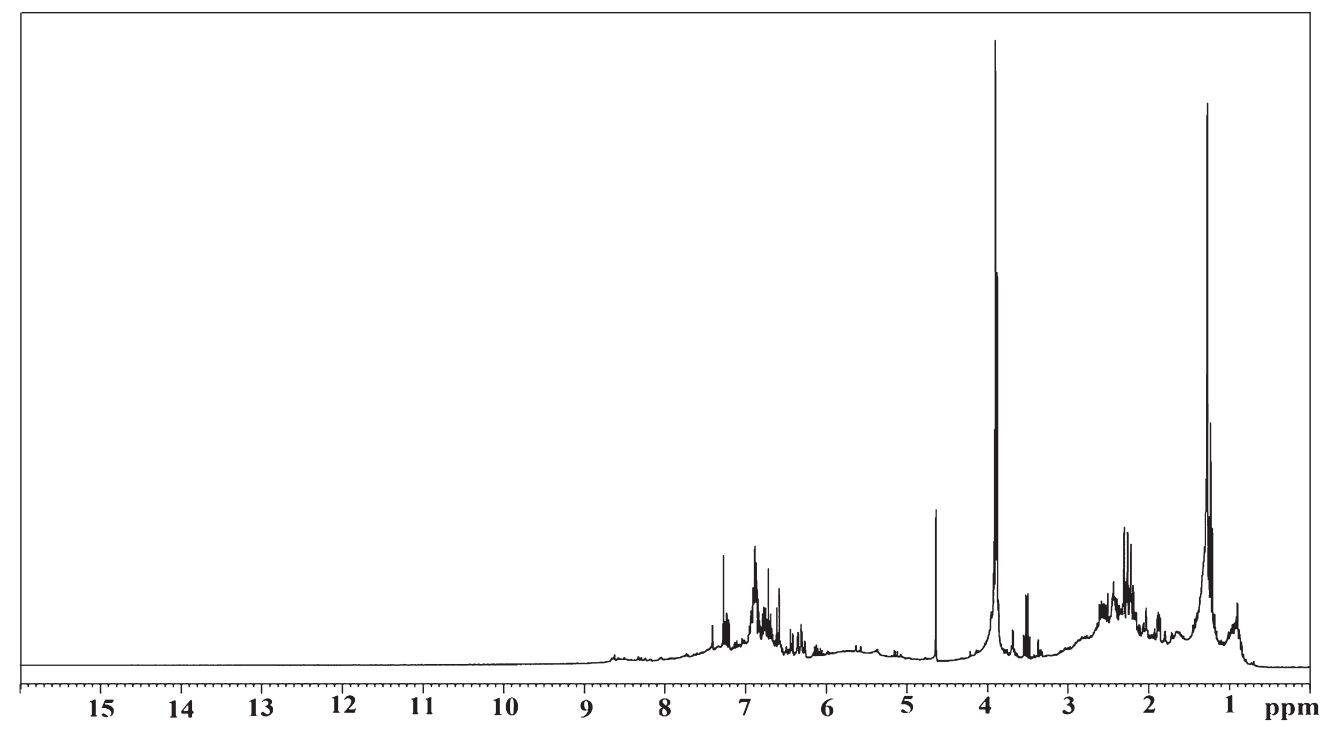

Figure $5{ }^{1} \mathrm{H}-\mathrm{NMR}$ spectrum of bio-oil Slika 5. ${ }^{1} \mathrm{H}-\mathrm{NMR}$ spektar bioulja 
Table 3 Main organic components of bio-oils ${ }^{\mathrm{a}}$ with GC/MS analysis

Tablica 3. Glavne organske komponente bioulja ${ }^{a}$ dobivene GC/MS analizom

\begin{tabular}{|c|c|c|c|c|}
\hline No & RT (min) & Name of compounds / Naziv komponente & $\begin{array}{c}\text { Area / Područje } \\
\%\end{array}$ & Category / Kategorija \\
\hline 1 & 23.02 & 2-cyclopenten-1-one & 1.38 & Ketone \\
\hline 2 & 23.31 & 2-methyl-2-cyclopenten-1-one & 0.84 & Ketone \\
\hline 3 & 25.13 & furfural & 2.06 & Aldehyde \\
\hline 4 & 25.85 & 1-(2-furanyl)-ethanone & 0.62 & Ketone \\
\hline 5 & 26.21 & 3-methyl-2-cyclopenten-1-one & 0.96 & Ketone \\
\hline 6 & 26.52 & 2,3-dimethyl-2-cyclopenten-1-one & 0.43 & Ketone \\
\hline 7 & 27.40 & butanoic acid & 0.56 & Acid \\
\hline 8 & 27.89 & 2-furanmethanol & 2.78 & Alcohol \\
\hline 9 & 29.42 & 1,2-cyclopentenedione & 1.55 & Ketone \\
\hline 10 & 29.68 & 2-hydroxy-3,4-dimethyl-2-cyclopenten-1-one & 0.38 & Ketone \\
\hline 11 & 29.83 & 3,4-dimethoxytoluene & 0.59 & Benzene \\
\hline 12 & 30.18 & 2-hydroxy-3-methyl-2-cyclopenten-1-one & 3.96 & Ketone \\
\hline 13 & 30.62 & 2-methoxy-phenol & 11.82 & Phenol \\
\hline 14 & 30.77 & 2-methoxy-3-methyl-phenol & 0.69 & Phenol \\
\hline 15 & 31.06 & 3-ethyl-2-hydroxy-2-cyclopenten-1-one & 0.80 & Ketone \\
\hline 16 & 32.00 & 4-methyl-phenol & 13.06 & Phenol \\
\hline 17 & 32.15 & ethanone & 0.73 & Ketone \\
\hline 18 & 32.23 & maltol & 0.70 & Alcohol \\
\hline 19 & 32.50 & 2-methyl-phenol & 1.50 & Phenol \\
\hline 20 & 32.59 & phenol & 2.25 & Phenol \\
\hline 21 & 33.18 & 4-ethyl-2-methoxy-phenol & 7.12 & Phenol \\
\hline 22 & 33.87 & 2,6-dimethyl-phenol & 1.07 & Phenol \\
\hline 23 & 33.94 & 4-methyl-phenol & 1.36 & Phenol \\
\hline 24 & 34.10 & 3-methyl-phenol & 1.53 & Phenol \\
\hline 25 & 34.66 & 2-methoxy-4-(1-propenyl)-phenol & 1.67 & Phenol \\
\hline 26 & 35.94 & 2-methoxy-4-(2-propenyl)-phenol & 3.35 & Phenol \\
\hline 27 & 36.67 & 2-methoxy-4-vinyl-phenol & 3.11 & Phenol \\
\hline 28 & 38.28 & 2-methoxy-4-propenyl-phenol & 1.63 & Phenol \\
\hline 29 & 41.38 & 2-methoxy-4-propenyl-phenol & 8.52 & Phenol \\
\hline 30 & 51.39 & 4-hydroxy-3-methoxy-benzaldehyde & 3.01 & Aldehyde \\
\hline 31 & 55.81 & 1,2-benzenediol & 4.81 & Phenol \\
\hline 32 & 58.57 & 4-methyl 1,2-benzenediol & 2.72 & Phenol \\
\hline Total / Ukupno & & & 87.56 & \\
\hline
\end{tabular}

aobtained at $500{ }^{\circ} \mathrm{C} /$ dobiveno pri $500^{\circ} \mathrm{C}$

Table 4 Elemental composition of bio-char ${ }^{\mathrm{b}}$

Tablica 4. Elementarni sastav biougljena ${ }^{b}$

\begin{tabular}{|l|c|c|c|c|c|c|}
\hline $\begin{array}{l}\text { Component } \\
\text { Komponenta }\end{array}$ & $\begin{array}{c}\mathbf{C} \\
\%\end{array}$ & $\begin{array}{c}\mathbf{H} \\
\%\end{array}$ & $\begin{array}{c}\mathbf{O}^{\mathrm{a}} \\
\%\end{array}$ & $\mathbf{H} / \mathbf{C}$ & $\mathbf{O} / \mathbf{C}$ & $\begin{array}{c}\mathbf{H H V}^{\mathrm{c}} \\
\mathbf{M J} / \mathrm{kg}\end{array}$ \\
\hline $\begin{array}{l}\text { Value } \\
\text { Vrijednost }\end{array}$ & 77.28 & 3.91 & 18.81 & 0.60 & 0.18 & 28.35 \\
\hline
\end{tabular}

${ }^{a}$ by difference, ${ }^{b}$ obtained at $500{ }^{\circ} \mathrm{C}$; ${ }^{c} \mathrm{HHV}$ calculated by Dulong Formula, that is, HHV $(\mathrm{MJ} / \mathrm{kg})=0.338 \mathrm{C}+1.428(\mathrm{H}-$ $\mathrm{O} / 8)+0.095 \mathrm{~S}$

bio-char were determined when FT-IR spectra of biochar and raw material were compared. FT-IR spectrum of the bio-char was simplified. In FT-IR spectrum of raw material, the $\mathrm{O}-\mathrm{H}$ stretching vibration band observed between 3600 and $32001 / \mathrm{cm}$, the C-H stretching vibration band observed between 2935 and $28851 /$ $\mathrm{cm}$ and the $\mathrm{C}=\mathrm{O}$ stretching vibration band observed between 1740 and $17001 / \mathrm{cm}$ were not found in the bio-char obtained from the pyrolysis of fir wood saw- dust. The bio-char loses both hydroxyl and aliphatic groups and the aromatic character increases quite rapidly above $450{ }^{\circ} \mathrm{C}$ (Sharma et al., 2004).

\section{CONCLUSIONS \\ 4. ZAKLJUČAK}

In this paper, the fir wood sawdust was pyrolyzed to convert into bio-oil and bio-char using a fixed-bed reactor at different pyrolysis temperatures, and their chemical properties were characterized. The yields of pyrolytic products distribution, bio-oil, bio-char and gases, was significantly influenced by pyrolysis temperatures. The maximum bio-oil yield of $45.9 \mathrm{wt} \%$ was obtained at the final pyrolysis temperature of $500{ }^{\circ} \mathrm{C}$. The bio-oil derived from fir wood sawdust consisted of about 32 major compounds, including phenols, organic acids, aldehydes, ketones and alcohols. The chemical properties have shown that the bio-oil obtained from fir wood sawdust could be use as a feedstock, and that it was an ideal candidate for alternative fuels. Moreover, the biochar can be used as an energy source and active carbon. 


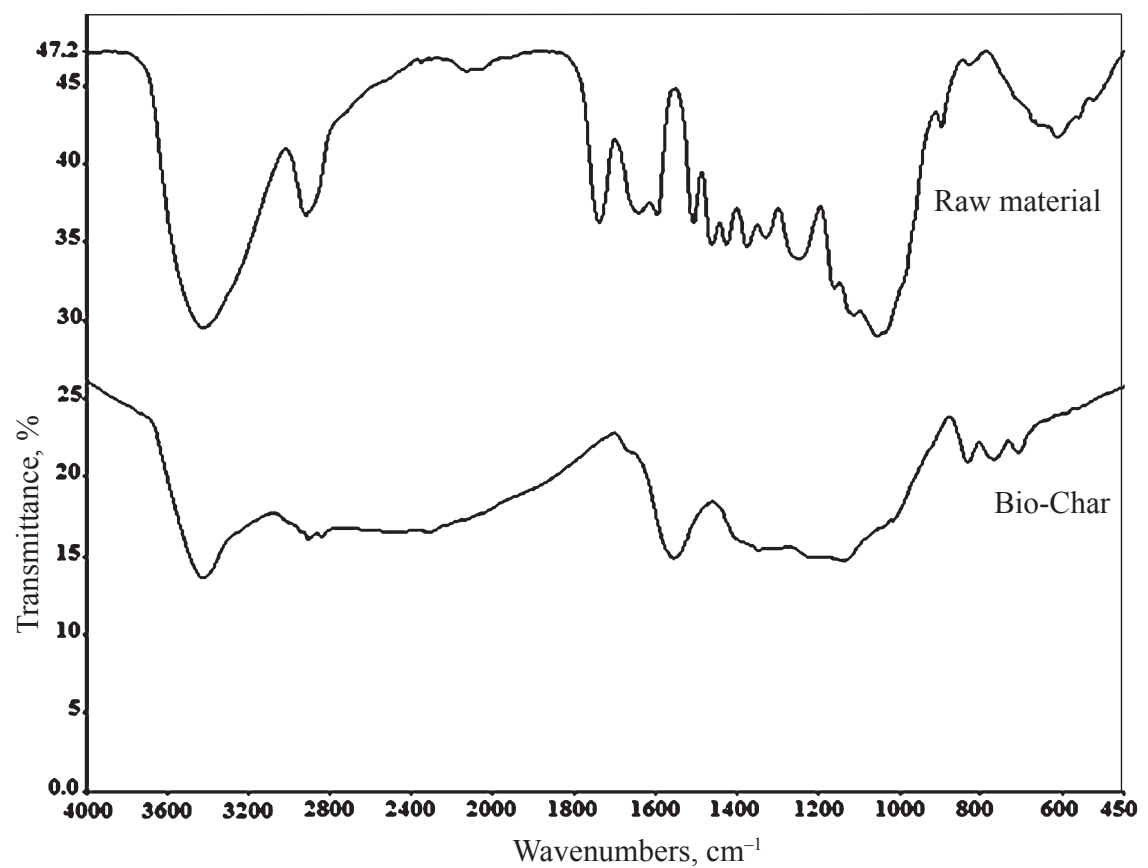

Figure 6 FTIR spectra of raw material and bio-char Slika 6. FTIR spektar sirovine i biougljena

\section{Acknowledgements - Zahvala}

The author is grateful to Dr. Ayben KILIÇ, Mehmet Hacı KAYILI and Yasemin DİÇOFLAZ for chemical analysis. Thanks also to Jackie ALEXANDER for the proofreading.

\section{REFERENCES}

\section{LITERATURA}

1. Ac1kgoz, C.; Kockar, O. M., 2009: Characterization of slow pyrolysis oil obtained from linseed (Linumusitatissimum L.). Journal of Analytical and Applied Pyrolysis, 85: 151-154.

http://dx.doi.org/10.1016/j.jaap.2008.08.011

2. American Society for Testing and Materials. 1997: Standard test method for direct moisture content measurement of wood and wood-base materials. ASTM Standarts D 4442-92. Easton, M.D., USA.

3. American Society for Testing and Materials. 2004: Standard test method for volatile matter in analysis sample refuse derived fuel. ASTM Standarts E-897-88., Easton, M. D., USA.

4. American Society for Testing and Materials. 1983: Standard test method for ash in wood. ASTM Standarts D-1102-84., Easton, M. D., USA.

5. Bridgwater, A. V., 2003: Renewable fuels and chemicals by thermal processing of biomass. Chemical Engineering Journal, 91 (2-3): 87-102. http://dx.doi.org/10.1016/S1385-8947(02)00142-0

6. Bridgwater, A. V., 2004: Biomass fast pyrolysis. Thermal Science, 8 (2): 21-49. http://dx.doi.org/10.2298/TSCI0402021B

7. Bu, Q.; Lei, H.; Ren, S. J.; Wang, L.; Holladay, J.; Zhang, Q.; Tang, J.; Ruan, R., 2011: Phenol and phenolics from lignocellulosic biomass by catalytic microwave pyrolysis. Bioresource Technology, 102: 7004-7007. http://dx.doi.org/10.1016/j.biortech.2011.04.025

8. Beis, S. H.; Onay, Ö.; Koçkar, Ö. M., 2002: Fixed-bed pyrolysis of safflower seed: Influence of pyrolysis pa- rameters on product yields and compositions. Renewable Energy, 26(1): 21-32.

http://dx.doi.org/10.1016/S0960-1481(01)00109-4

9. Chen, M.; Wang, J.; Zhang, M.; Chen, M.; Zhu, X.; Min, F.; Tan, Z., 2008: Catalytic effects of eight inorganic additives on pyrolysis of pine wood sawdust by microwave heating. Journal of Analytical and Applied Pyrolysis, 82 (1): $145-150$.

http://dx.doi.org/10.1016/j.jaap.2008.03.001

10. Demiral, İ.; Ayan, E. A., 2011: Pyrolysis of grape bagasse: Effect of pyrolysis conditions on the product yields and characterization of the liquid product. Bioresource Technology, 102: 3946-3951.

http://dx.doi.org/10.1016/j.biortech.2010.11.077

11. Duman, G.; Okutucu, C.; Uçar, S.; Stahl, R.; Yanık, J., 2011: The slow and fast pyrolysis of cherry seed. Bioresource Technology, 102: 1869-1878.

http://dx.doi.org/10.1016/j.biortech.2010.07.051

12. Encinar, J. M.; González, J. F.; Martinez, G.; Román, S., 2009: Catalytic pyrolysis of exhausted olive oil waste. Journal of Analytical and Applied Pyrolysis, 85 (1-2): 197-203. http://dx.doi.org/10.1016/j.jaap.2008.11.018

13. Ertaş, M.; Alma, H. M., 2010: Pyrolysis of laurel (Laurus nobilis L.) extraction residues in a fixed-bed reactor characterization of bio-oil and bio-char. Journal of Analytical and Applied Pyrolysis, 88 (1): 22-29. http://dx.doi.org/10.1016/j.jaap.2010.02.006

14. Fagbemi, L.; Khezami, L.; Capart, R., 2001: Pyrolysis products from different biomasses: application to the thermal cracking of tar. Applied Energy, 69: 293-306. http://dx.doi.org/10.1016/S0306-2619(01)00013-7

15. Heigenmoser, A.; Liebner, F.; Windeisen, E.; Richter, K., 2013: Investigation of thermally treated beech (Fagus sylvatica) and spruce (Picea abies) by means of multifunctional analytical pyrolysis-GC/MS. Journal of Analytical and Applied Pyrolysis, 100: 117-126. http://dx.doi.org/10.1016/j.jaap.2012.12.005

16. Heo, S. H.; Park, H. J.; Park, Y.-K.; Ryu, C.; Suh, D. J.; Suh, Y.-W.; Yim, J.-H.; Kim, S.-S., 2010: Bio-oil production from fast pyrolysis of waste furniture sawdust in a 
fluidized bed. Bioresource Technology, 101 (1): 91-96. http://dx.doi.org/10.1016/j.biortech.2009.06.003

17. Ingram, L.; Mohan, D.; Bricka, M.; Steele, P.; Strobel, D., 2008: Pyrolysis of wood and bark in an auger reactor: Physical properties and chemical analysis of the produced bio-oils. Energy\&Fuels, 22: 614-625. http://dx.doi.org/10.1021/ef700335k

18. Janse, A. M. C.; Westerhout, A. M. C; Prins W., 2000: Modelling of flash pyrolysis of a single wood particle. Chemical Engineering and Processing 39: 239-252. http://dx.doi.org/10.1016/S0255-2701(99)00092-6

19. Kim, K. H.; Eom, I. Y.; Lee, S. M., Choi, D.; Yeo, H.; Choi, I.-G.;. Choi, J. W., 2011: Investigation of physicochemical properties of bio-oils produced from yellow poplar wood (Liriodendron tulipifera) at various temperatures and residence times. Journal of Analytical and Applied Pyrolysis 92: 2-9.

http://dx.doi.org/10.1016/j.jaap.2011.04.002

20. Lee, K. H.; Kang, B. S.; Park, Y. K.; Kim, J. S., 2005: Influence of reaction temperature, pretreatment, and a char removal system on the production of bio-oil from rice straw by fast pyrolysis, using a fluidized bed. Energy \& Fuels, 19: 2179-2184. http://dx.doi.org/10.1021/ef050015o

21. Liaw, S.-S.;Wang, Z.; Ndegwa, P.; Frear, C.; Ha, S.; Li, C.-Z.; Garcia-Perez, M., 2012: Effect of pyrolysis temperature on the yield and properties of bio-oils obtained from the auger pyrolysis of Douglas Fir wood. Journal of Analytical and Applied Pyrolysis, 93: 52-62. http://dx.doi.org/10.1016/j.jaap.2011.09.011

22. Lu, Q.; Wang, Z.; Dong, C.; Zhang, Z.; Zhang, Y.; Yang, Y.; Zhu, X., 2011: Selective fast pyrolysis of biomass impregnated with $\mathrm{ZnCl}_{2}$ : Furfural production together with acetic acid and activated carbon as by-products. Journal of Analytical and Applied Pyrolysis, 91 (1): 273-279. http://dx.doi.org/10.1016/j.jaap.2011.03.002

23. Lu, Q.; Zhang, Z.-F.; Dong, C.-Q.; Zhu, X.-F., 2010: Catalytic Upgrading of Biomass Fast Pyrolysis Vapors with Nano Metal Oxides: An Analytical Py-GC/MS Study. Energies, 3: 1805-1820. http://dx.doi.org/10.3390/en3111805

24. Luo, Z.; Wang, S.; Liao, T.; Zhou, J.; Gu, Y.; Cen, K., 2004: Research on biomass fast pyrolysis for liquid fuel. Biomass\&Bioenergy, 26: 455-462. http://dx.doi.org/10.1016/j.biombioe.2003.04.001

25. Murataa, K.; Liua,Y.; Inabaa, M.; Takaharaa, I., 2012: Catalytic fast pyrolysis of jatropha wastes. Journal of Analytical and Applied Pyrolysis, 94: 75-82. http://dx.doi.org/10.1016/j.jaap.2011.11.008

26. Onay, O., 2007: Fast and catalytic pyrolysis of pistaciakhinjuk seed in a well-swept fixed bed reactor. Fuel, 86: $1452-1460$ http://dx.doi.org/10.1016/j.fuel.2006.12.017

27. Özbay, G., 2012: Liquefaction of wood and wood-based composed materials sawdust by thermal and catalytic pyrolysis method. PhD Thesis, Karabük University, Graduate School of Natural and Applied Sciences, Karabük, 96-99, 2012.

28. Özçifçi, A.;Özbay, G., 2013: Bio-oil production from catalytic pyrolysis method of furniture industry sawdust. Journal of the Faculty of Engineering and Architecture of Gazi University, 28, (3): 473-479.

29. Özbay, G.; Özçifçi, A.; Karagöz, S., 2013: Catalytic pyrolysis of waste melamine coated chipboard. Environmental Progress \& Sustainable Energy, 32 (1): 156-161. http://dx.doi.org/10.1002/ep.10612

30. Özçimen, D.; Ersoy-Meriçboyu, A., 2010: Characterization of biochar and bio-oil samples obtained from car- bonization of various biomass materials. Renewable Energy, 35: 1319-1324.

http://dx.doi.org/10.1016/j.renene.2009.11.042

31. Pütün, A.; Özbay, N.; Önal, E. P.; Pütün, E., 2005: Fixedbed pyrolysis of cotton stalk for liquid and solid products. Fuel Processing Technology, 86: 1207-1219. http://dx.doi.org/10.1016/j.fuproc.2004.12.006

32. Rowell, R. M.; Pettersen, R.; Han, J. S.; Rowell, J. S.; Tshabalala, M. A., 2005: Handbook of wood chemistry and wood composites, CRC Press, Boca Raton, pp. 72487.

33. Ren, S.; Hanwu Lei, H.; Wang L.; Quan, Q.; Chen, S.; Wu, J.; Julson, J.; Ruan, R., 2012: Biofuel production and kinetics analysis for microwave pyrolysis of Douglas fir sawdust pellet. Journal of Analytical and Applied Pyrolysis, 94: 163-169. http://dx.doi.org/10.1016/j.jaap.2011.12.004

34. Sadaka, S., 2009: Pyrolysis. Associate Scientist Center of SustinableEnviroment Technologies, Iowa State Universty, Nevada, 2-22.

35. Shen, D. K.; Gu, S., 2009: The mechanism for thermal decomposition of cellulose and its main products. Bioresource Technology, 100: 6496-6504. http://dx.doi.org/10.1016/j.biortech.2009.06.095

36. Shen, D. K.; Gu, S.; Bridgwater, A. V., 2010: Study on the pyrolyticbehaviour of xylan-based hemicellulose using TG-FTIR and Py-GC-FTIR. Journal of Analytical and Applied Pyrolysis, 87: 199-206. http://dx.doi.org/10.1016/j.jaap.2009.12.001

37. Sheng, C.; Azevedo, J. L. T., 2005: Estimating the higher heating value of biomass fuels from basic analysis data. Biomass and Bioenergy, 28 (5): 499-507. http://dx.doi.org/10.1016/j.biombioe.2004.11.008

38. Sharma, R. K.; Wooten, J. B.; Baliga, V. L.; Lin, X.; Chan, W. G.; Hajaligol, M. R., 2004: Characterization of chars from pyrolysis of lignin. Fuel, 83: 1469-1482. http://dx.doi.org/10.1016/j.fuel.2003.11.015

39. Şensöz, S., 2003: Slow pyrolysis of wood barks from PinusbrutiaTen. and product compositions. Bioresource Technology, 89 (3): 307-311. http://dx.doi.org/10.1016/S0960-8524(03)00059-2

40. Technical Association of the Pulp and Paper Industry (1993). Sampling and preparing wood for analysis. TAPPI T 257cm-12, Tappi Pres. Atlanta, GA, USA.

41. Technical Association of the Pulp and Paper Industry (2002). Acid-insoluble lignin in wood and pulp. TAPPI T 222 om-02, Tappi Pres. Atlanta, GA, U.S.A.

42. Technical Association of the Pulp and Paper Industry (1997). Solvent extractives of wood and pulp. TAPPI T $204 \mathrm{~cm}-97$, Tappi Pres. Atlanta, GA, USA.

43. Uzun, B. B.; Sarığlu, N., 2009: Rapid and catalytic pyrolysis of corn stalks.Fuel Processing Technology, 90: 705-716. http://dx.doi.org/10.1016/j.fuproc.2009.01.012

44. Wagenaar, B. M.; Prins, W.; van Swaaij, W. P. M., 1993: Flash pyrolysis kinetics of pine wood. Fuel Processing Technology, 36: 291-302. http://dx.doi.org/10.1016/0378-3820(93)90039-7

45. Wang, C.; Du, Z.; Pan, J.; Li, J.; Yang, Z., 2007: Direct conversion of biomass to bio-petroleum at low temperature. Journal of Analytical and Applied Pyrolysis, 78 (2): 438-444. http://dx.doi.org/10.1016/j.jaap.2006.10.016

46. Wang, Z.; Cao, J.; Wang, J., 2009: Pyrolytic characteristics of pine wood in a slowly heating and gas sweeping fixed-bed reactor. Journal of Analytical and Applied Pyrolysis, 84 (2): 179-184.

http://dx.doi.org/10.1016/j.jaap.2009.02.001 
47. Wise, L. E.; John, E. C., 1952: Wood chemistry. Reinhold Publication Co, New York, 1-2: 1330.

48. Wörmeyer, K.; Ingram, T.; Saake, B.; Brunner, G.; Smirnova, I., 2011.: Comparison of different pretreatment methods for lignocellulosic materials. Part II: Influence of pretreatment on the properties of rye straw lignin. Bioresource Technology, 102: 4157-4164. http://dx.doi.org/10.1016/j.biortech.2010.11.063

49. Yang, H.; Yan, R.; Chen, H.; Lee, D. H.; Zheng, C., 2007: Characteristics of hemicellulose, cellulose and lignin pyrolysis. Fuel, 86 (12-13): 1781-1788. http://dx.doi.org/10.1016/j.fuel.2006.12.013

50. Žilnik, L. F.; Jazbinšek, A., 2012: Recovery of renewable phenolic fraction from pyrolysis oil. Separation and Purification Technology, 86: 157-170.

http://dx.doi.org/10.1016/j.seppur.2011.10.040.

\section{Corresponding address:}

Assist. Prof. GÜNAY ÖZBAY, Ph.D.

Department of Forest Product Engineering Faculty of Forestry, Karabuk University

Karabuk, TURKEY

e-mail: gozbay@karabuk.edu.tr 